\title{
Teacher Leadership Behaviors on Sport Class
}

\author{
Pandit Isbianti \\ Educational Administration Department \\ Faculty of Educational Science \\ Universitas Negeri Yogyakarta \\ panditisbianti@uny.ac.id
}

\begin{abstract}
Quality learning is the important thing to the school advance. In fact, learning activities cannot be separated from the behavior of teacher leadership. To give more explanation about the kind of teacher leadership behaviors, the author conducted a study that aimed to explore the teacher leadership behaviours based on appear phenomena. This paper presents one of the main results of the research related to teacher leadership behaviors, which are divided into teacher leadership within and beyond classroom. Teacher leadership behaviours in class room consisted of: the use of professional expertise; designing curriculum; pair and partner collaboration through team teaching and role across collaboration. Teacher leadership behavior beyond the class room consisted of: teacher professional development activities, role-alike team collaboration, sharing professional responsibility with the school principal, collaboration with the student's family, establishing partnerships, and establishing the success culture to the students. This study conducted in sport class, so that gave the new nuance to teacher leadership. On sport class, the students have to join a sport training program besides participating in learning activities as well as regular classes. This situation encourages the emergence of various phenomena in the sport class, which encourage the emergence of teacher leadership behavior. In other words, this paper presents the contextual research results, which offer several alternatives of teacher leadership behavior, especially in schools that have the same character as that in this research.
\end{abstract}

Keywords-teacher leadership, teacher leadership behaviour, sport class.

\section{INTRODUCTION}

The school advance is a pride for the school and society demanded. Therefore, the importance of school advance should be realized as a necessity. Schools advance is influenced by various aspects, one of which is the quality learning. Quality learning needs the good teacher leadership behaviors. In other words, teacher leadership behavior is important to achieve the school advance $[1,2]$. Teachers should realize the importance of teacher leadership behavior, whether they teach in regular class or class that have special characteristics such as sport class. In sport class, students are required to undergo not only learning activity like the regular class, but also more exercise training program to support and strengthen student's sport potency. To support the sport class students both in learning and developing sport potency, teacher leadership is needed. There are many studies related to teacher leadership have been done. Nevertheless, there studies were conducted in regular classes which had similar characteristics. Therefore, this study provides new nuances for teacher leadership because it was conducted in a school which held a program whose characteristics were different from regular classes. The research was conducted to study the teacher leadership behavior in public senior high school I of Sewon Bantul, which held the sport class. The main research question in this research exploring teacher leadership behavior. The research results shown that teacher leadership behavior in sport class can be found either within and beyond classroom. Teacher leadership behavior in the classroom consisted of using of professional expertise; designing curriculum; pair and partner collaboration through team teaching and role accross collaboration. Meanwhile the teacher leadership behavior beyond classroom consisted of teacher professional development program, role-alike team collaboration, sharing professional responsibility with the school principal, collaboration with the student's family, establishing partnerships, and establishing a success culture to the students.

\section{RESEARCH METHODOLOGY}

The study about teacher leadership behavior in sport class is the qualitative research with phenomenology approach, to describe several individual's phenomenoa [3]. Therefore, this study was conducted to capture and describe various phenomena related to teacher leadership which were experienced by respondents. The subjects in this study were determined by purposive sampling which consisted of sport class teachers, sport class students, school principals, and school library coordinator. Data in this study were collected by in-depth interviews and observations, and were analyzed by using a Miles and Huberman model which consisted of data reduction, data display, and conclusion drawing / verification [4].

\section{RESULT AND DISCUSSION}

Teacher leadership behaviors in Senior public High School I of Sewon, Bantul consisted of teacher leadership in and beyond classroom. 
Teacher Leadership Behavior in Classroom

Using of Professional Expertise

The use of professional expertise is the application of teacher's knowledge and skills to create a conducive learning atmosphere. The use of professional expertise in sport class is so varied, but the impact is not necessarily the same. Even with the same phenomenon, if were applied using a different professional skills, the results are not necessarily the same. In other words, the use of different professional shows the correlation between leadership behavior in the classroom with the effort and student satisfaction, as stated by Pounder [5]: "leadership behavior in the classroom is positively related to student's extra effort, perceived instructor effectiveness, and student satisfaction." Thus, it is not surprising that the use of professional expertise as produces leads to the effective and ineffective results. The teacher leadership behavior which was applied to the phenomenon of students chatting up to each other during learning activities in class include: providing a direct warning to the students, changing teaching strategies and carrying out shock therapy, and establishing close relationship between teachers and students to change the student's mindset. The effort to change the teaching strategy is one of many factors driven by the self-evaluation performed by teachers on a personal initiative. At the time of evaluation, the teacher tried to selfreflection in order to estimate the causes that led to the students chatting up to each other during the learning activity. Teacher's effort for self-reflection is one of the characteristics of a successful leader [6]. On the sleepy students phenomenon, teachers leadership behavior include: doing shock therapy and providing direct warning. When the sport class students attended the class late, teacher leadership behaviors which were applied include: reprimanding the students and cooperating with the homeroom teacher, not giving permission for students to go to class, and imposing a fine. When the sport students not completing the task assigned by the teacher, the teacher leadership behaviors applied include: asking the student's difficulties and providing assistance, involving the students in a task discussion and not giving any mark to students. On the phenomenon of students said "huh" to a friend who was being advised by teachers, teacher leadership were giving the advice or reprimanding the students. On the phenomenon of students inappropriate clothes, teachers leadership behaviors include: asking students to tidying up their clothes before the lesson and imposing a fine.

\section{Designing Curriculum}

Designing curriculum is made to create an atmosphere of desired learning. Teacher leadership behavior in designing the curriculum include: creating conducive learning based on the situation, considering student's suggestions about learning strategy, giving aperception about desired student's achievement, reminding the students to learn the upcoming materials, using the humanism approach, encouraging student participation and using the learning methods accordance with the material.

Pair and Partner Collaboration through Team Teaching

Team teaching in the english subject were done in Public Senior High School I of Sewon Bantul was a pair and partner collaboration, enabled teachers to improve the colleagues proffesional skills by sharing their professional expertise. This team teaching consisted of one senior teacher and one junior teacher.

\section{Across Roles Collaboration}

Across roles collaboration were done by involving the library. The use of learning methods involved the library was accordance with [7]:

"Methods of teaching and learning should be Directly Also related to library use. Reading materials and audiovisual aids need to be readily available to assist learner to the make continual progress. Library experiences should relate to ongoing lessons and units of study. Thus, library materials may relate to a topic being pursued in the classroom. This might well involve; giving an oral or written book report, or a paper being developed. Students need to familiarize Themselves with services offered by school library. Reviews These services extend the learning secured by students in the classroom."

The statement above explains that learning activities should involve the use of the library to achieve the student's better achievement. Thus, this collaboration, should be maintained.

\section{Teacher Leadership Behavior beyond Classroom}

\section{Teacher Professional Development Activities}

Teacher leadership behavior to develop the teacher's professionalism in sport class of public senior high school I of Sewon, Bantul consisted of: training or seminar, continuing the study, and becaming a member of professional associations.

Ediger and Rao's statement is reinforced by [8] who state that teacher education can be a power central for qualified education in the future. In order to working well, teacher professional development needs the school principal's role. As the developer of community leaders, it is only proper if the principals provide an opportunity for teachers to develop themselves. Teacher professional development activity also expected to improve the learning effectiveness and partnership. [9]

\section{Role Alike Team Collaboration}

Role alike team collaboration in sport class of public senior high school I of Sewon, Bantul consisted of holding regular meetings regularly to solving the problems and to coordinate, doing informal communication to support the teachers, and making the decision by considering the student's suggestions. Those behaviors described the 
situation between principals and teachers as well as teachers and students in which has an equal right to be heard, as stated:

"True role alike colaboration does not occur when individuals sit together but do not share membership. it's easy enough to be critical of a person or an idea. supporting means leading others through the process of building trust and making room for consensus to occur. following does not have to mean going along with ideas or processes that fall outside our values [10]."

\section{Share Professional Responsibility with School Principal}

Professional responsibility shared between the school principal to teachers is related to teaching learning problems, which consisted of providing the learning tools such as computers, encouraging teachers, developing the learning materials and providing consultation to teachers related to the preparation of learning tools, to giving information about professional development opportunities and providing the opportunity for teachers to develop professionalism, supporting teacher learning programs, and encouraging teachers to do research. From the above statement, it can be understood that sharing professional responsibility occurs when the principal provides support to teachers to carry out their professional duties, and the teachers can do their jobs due to the school principal's support. Thus, the principal is a supporting factor for teacher leadership [11].

\section{Collaboration with Student's Family.}

Collaborating with student's family can be defined as the involvement of parents in the educational process. Collaboration with the student's family in Public High School I of Sewon Bantul done by coordinating with parents. Through this coordination, the school expects the parents to care and support their children's education.

\section{Establish Partnership}

To support the implementation of the sport class program especially in exercise program, the school established partnerships with several parties. The partnership is made on the basis of mutual benefit. In this case, the partnership were done with the educational Office of Bantul, sport committee of Bantul, State university of Yogyakarta and many other schools.

\section{Maintaining a Success Culture}

Teacher leadership in preserving the culture of success in Public High School I of Sewon Bantul include: providing motivation to students to be enthusiastthic in learning and obey the rules, instilling self of belonging toward the school, having informal communications, instilling the importance of English to the students, providing motivation vary ways, and encouraging students to be commited to the assignment of sport class student. One way to motivate students is by giving them insights about various possibilities that may occur in their future, so that they can be more motivated to learn. Provide a stimulus to students so that students can do their own search allows the student to change, stated by [12]:

Teachers can help to channel Efforts in a positive direction by exposing students to new ideas and broadening vision. Educators can start (students) on an journey of selfdiscovery, to help them find Reviews their own self-worth and their ability to change.

\section{CONCLUSION}

The study on teacher leadership behaviour was reported. Leadership behavior of teachers is an important thing, which leads to successful learning process. The results of this study are contextual so they cannot be applied to schools with different characteristics than those in the study. Nevertheless, the results of this study can serve as a reference or benchmark for schools that have similar characteristics. Considering the importance of the positive impact generated by teacher leadership behaviors, study about the factors influencing teacher leadership behaviors need to do in the future, so they can be used to improve teacher leadership behaviors.

\section{REFERENCES}

[1] Danielson, C. (2006). Teacher leadership that strengthens professional practice. Virgina USA: ASCD Publication.

[2] National Comprehensive Center for Teacher Quality. (2007). Enhancing teacher leadership. Washington, DC: A collaborative effort of education commission of the States, ETS, Learning Point Associates, and Vanderbilt University.

[3] Cresswell, J.W. (2007). Qualitative inquiry \& research designchoosing among five approaches. California: Sage Publications. [3]

[4] Milles, M.B. \& Huberman, M.A. (2007). Analisis data kualitatifbuku sumber tentang metode-metode baru. (Terjemahan Tjetjep Rohendi Rohidi \& Mulyarto). Jakarta: UI press.

[5] Goodboy, A.K. \& Bolkan, S. (2011). Leadership in the college classroom: The use of charismatic leadership as a deterrent to student resistance strategies.Classroom Interaction. 46, 4-10.

[6] Connors, N. (2000). If you don't feed the teachers they eat the students-Guide to success for administrators and teachers. Nashville: Incentive Publications.

[7] Gigante, N.A. \& Firestone, W.A. (2007). Administrative support and teacher leadership in school implementing reform. Educational Administrations, 46, 302-331.

[8] Ganihar, N.N. \& Nayak, V.S. (2007). Human resource development and teacher education. New Delhi: Discovery publishing house.

[9] Rutherford, C. (2006). Teacher leadership and organizational structure-The implications of restructured leadership in an Edison school Educational. Change. 7. 59-76.

[10] Collay, M. (2011). Everyday teacher leadership-taking action where you are. USA: Jossey Bass.

[11] Ediger, M. \& Rao, D.B. (2010). Effective Schooling. New Delhi: Mehra Offset Press.

[12] Potter, Tami, K. (September 2001). Teacher leadership. Correctional Education. 52, Artikel 3. 120-125. 